\title{
The Use of Communicative Language Learning (CLL) to Teach Speaking at a Taiwanese Elementary School: Implementation and Students' Responses
}

\author{
Laura Yosephine Tan, ${ }^{1}$ Listyani Listyani ${ }^{*}$ \\ ${ }^{1,2}$ Fakultas Bahasa dan Seni, Universitas Kristen Satya Wacana, Jl. Diponegoro \\ No.52-60, Salatiga, Kec. Sidorejo, Kota Salatiga, Jawa Tengah 50711, Indonesia \\ ${ }^{*}$ Corresponding Author \\ Email: listyani@staff.uksw.edu \\ DOI: 10.18326/rgt.v13i2.257-276
}

Submission Track:

Received: 10-06-2020

Final Revision: 13-10-2020

Available Online: 01-12-2020

Copyright @ 2020 Laura Yosephine Tan, Listyani Listyani

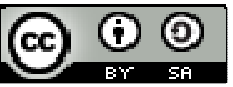

This work is licensed under a Creative Commons Attribution-ShareAlike 4.0

International License.

\begin{abstract}
Speaking is one of the important skills to master. The importance of learning speaking skills helps people to share their ideas, agreement or disagreement, compliments, and so on to others. Some students feel a lack of practice in learning English because of the insufficient support they receive, including those in Taiwan. Therefore, the purpose of this study is to investigate how Taiwanese teachers apply CLL in speaking activities and the students' responses towards speaking activities which implement CLL at an elementary school in Taiwan. Data for this qualitative study were gathered from semi-structured interviews and reflective journals. The participants were one Taiwanese English teacher and 64 elementary school students, grade 4 and 5. Data from the semi-structured interview were recorded, then transcribed. Only one teacher was interviewed because she was the only English teacher at that school who was willing to be interviewed. After that, themes were drawn based on the transcribed interviews. Based on the data, it was found that the Taiwanese English teacher who taught English at that particular elementary school applied CLL to teach the English language. Some activities such as group discussion and Think-Pair-Share were done. In the Taiwanese elementary school where the study was conducted, these activities were found useful because students could gain more vocabulary, a fun atmosphere created inside the classroom, and better fluency and pronunciation.
\end{abstract}

Keywords: speaking; CLL; Taiwanese; elementary school; students' responses 


\section{INTRODUCTION}

In studying the English language, students are expected to master all skills like listening, reading, writing, and speaking. Speaking is one of the most difficult skills to master. In learning speaking skills, students may face some challenges like being afraid of the wrong grammatical accuracy and fluency, lack of vocabulary, and anxiety. Teaching speaking aims to encourage students to practice their speaking ability more often. Besides, when a teacher teaches speaking, the teacher often focuses more on tenses rather than giving the students opportunities to practice their oral skills. It can make students feel a lack of support from the teacher and chances to practice speaking. One of the strategies to make students practice speaking is CLL. This study focused more on investigating how a Taiwanese English teacher applied CLL in speaking activities and describing students' responses towards speaking activities with the use of CLL at an elementary school in Taiwan.

At this particular elementary school, the stages of learning the English language are writing, reading, listening, and speaking. English teachers focused more on reading and writing. Students had difficulties in practicing their English because they lacked support inside and outside the school. In school, the English teacher used CLL in teaching the English language. This strategy provides some variation of activities and tasks that could encourage students in their learning. There are team practices, jigsaw puzzles, and cooperative projects. These strategies were chosen because the activities and tasks gave students more time to practice rather than listen to the teacher.

Based on those facts, we saw there was an urgency to conduct research in this matter. This study will answer two research questions, which are as follows: How does the teacher apply CLL in speaking activities at a Taiwanese elementary school? What are the students' responses in speaking activities using CLL at that particular Taiwaese Elementary School?

The results of this study are expected to be beneficial to English teachers and students. The findings would hopefully be useful for English teachers, in general, to get more information about the activities and tasks to encourage students to learn the English language. The results may hopefully stimulate students by using some ways that were discussed in this study. 


\section{Speaking}

One of the important skills in learning the English language is speaking. Speaking is a way for people to interact and communicate with others to accomplish a discussion (Raba, 2017). Likewise, the importance of talk simplifies ideas, which is stated by Barner and Todd (1977). The purpose of speaking is to be able to use language for expressing ideas, feelings or something to others with interactive skills like greetings, apologies, agreement and disagreement, and so on. Some factors cause students in practicing a speaking skill. Khamkhien (2010) stated that some factors influence the students' speaking skill, e.g. age, native language, behavior, and experience in learning English.

Zhang (2009) claimed that speaking is the hardest skill to master and some ESL still have inability to communicate orally in the English language. It is difficult because there are some problems encountered in learning speaking like the lack of pronunciation, vocabulary, and tenses. Moreover, a lack of support in a classroom atmosphere will give students more anxiety in practicing their speaking ability. The fear of making a mistake while speaking, shyness, wrong tenses and so forth can cause students to show weak speaking skills. Besides, learning speaking is also learning to behave with each other while practicing oral skills.

\section{Teaching Speaking}

There are some elementary school students in general that lack good speaking skills because they may be afraid of making grammatical errors or pronunciations mistakes. English teachers should consider this issue. In learning a foreign language, teaching speaking for students is important because it can give students more support in practicing their speaking skills. One of the purposes of teaching speaking is motivating students to improve both their accuracy and fluency. Anuradha et al (2014) mentioned 10 important principles of teaching speaking skills. First, in teaching speaking, teachers should give support to students from the beginning. Next, students who tend to repeat what they say and answer many questions with only one word should be accepted. After that, students are free to speak with their background 
knowledge. Then, teachers can drill students with grammar use in many situations. Also, back-chaining or tail-forwarding methods to create complete sentences can boost students' speaking skill. Moreover, in practicing the language, the active and passive students can be controlled by doing role play and pair work. Furthermore, a lesson plan should be well prepared to help teachers while doing the teaching process. Also important for teachers is to give learners a chance to learn from their errors and give sympathy to each weaknesses.

Solcova (2011) illustrated the unsuccessful teaching of speaking that gives more attention to grammar and vocabulary rather than speaking opportunities does not improve students' speaking skills. Based on Solcova's illustration, teaching speaking can be useless when a teacher focuses more on vocabulary rather than the speaking skill itself. It would limit students' time to practice their speaking skill. Moreover, Kusrini (2012) claimed that vocabulary is the main factor that makes students have difficulties expressing their ideas to others. This may give an effect that some students, during a discussion, speak their mother tongue because it is easier to tell their idea by using the first language. Some teachers claim that cooperative learning can be beneficial for students who lack the opportunity to communicate. This strategy gives students more chance to have a conversation with others (Gao, 2011; Han, 2009; Huang, 2012; Ma, 2006; Nie, 2010).

\section{CLL (Cooperative Language Learning) Activities in English Lessons}

In cooperative learning, Jolliffe (2007) suggested that students work in a group to learn and support each other. Having CLL activities and tasks in any English classroom can develop the use of language in many situations. Slavin (1980) concluded that applying cooperative learning is the most effective environment in gaining students' attitudes and behaviors. By using this way students will not just interact in a group, but they are are learning to behave for each other during a discussion. Furthermore, one implication of Wanger and Wanger's (2015) cooperative learning is that participants in group work with the same task can comfort each other by having a conversation. The point is that cooperative learning can convince each individual in a group by interacting with them. In a cooperative learning strategy, there are several learning tasks 
like a jigsaw, group discussion (team practice), and cooperative projects. Calderon (1990) mentioned that the effectiveness of cooperative learning demands of teachers' commitments of time and effort. The point is teaching speaking using CLL activities in an English classroom can be useful for students and teachers.

Whereas some are convinced that cooperative learning allows students to practice their speaking skills, others view that cooperative learning is insufficient to help students in increasing students' pronunciation Han, 2006; Huang, 2011; Lin, 2009; Qiu, 2014). In making this comment, Slavin (1980) concluded that applying cooperative learning is the most effective environment in gaining students' attitudes and behaviors. By using this way students will interact in a group, given that they are assigned to behave for each other during a discussion. Furthermore, one implication of Wanger and Wanger's (2015) cooperative learning is that participants in group work with the same task can comfort each other by having a conversation. The point is that cooperative learning can convince each individual in a group by interacting with them. In a cooperative learning strategy, there are several learning tasks and learning focus like a jigsaw, group discussion (team practice), and cooperative projects.

\section{Jigsaw Task}

The first is Jigsaw-one of the tasks in cooperative learning. It involves dividing students into home groups, each discussing a different topic. After discussion, each group should rearrange into the topic groups to develop the materials. The last part involves students going back to the home groups to evaluate opinions. In this activity, students learn to evaluate their own learning by collaborating with two groups' members.

A student may feel uncomfortable with this activity. Aronson (1978) said that students in a group who have a higher level of understanding but have negative attitudes will rarely fail compared to those who with lower comprehension. Furthermore, Reese (2009) also mentioned the problem of using the jigsaw method. It is like gathering different levels of students in one group. It might make the low-level students feel difficulties. In short, the higher student's level will work more rather than the lower student's level. This may 
give low-level learners the feeling of hardship to follow a discussion. Based on those statements, Mengduo and Xiaoling (2010) argued that students may feel anxious self-esteem in a classroom.

Lin (2010) claimed that teachers and students from Taiwan use the Jigsaw technique in an English classroom. This activity is common in Taiwan for teaching speaking. Furthermore, Astane and Berimani (2014) said that the effectiveness of using jigsaw in speaking skill is to create a kind of team atmosphere among the groups. What is more important is the use of jigsaw in an English classroom gives an amazing effect to each individual for cooperative structure. Even though there might be a challenge, each student has an opportunity to practice their speaking skill.

\section{Group Discussion (Team Practice) Task}

The second task is a group discussion. This is similar to team practice because it enables developing and mastering a topic by taking part in group work. Antoni (2014) put forth that the method of using small group discussion is as follows: a teacher will divide students into several groups, each group with a different topic. The teacher should give roles to students and every group must discuss the given topic. Hamzah and Ting (2010) showed the students' positive replies about the group work activities in a classroom. Positive replies mean students can learn from others while discussing a topic.

When it comes to the topic of a group discussion activity, most students will readily agree that it will give positive feedback to students in a classroom. Nihalani, et al (2010) found out that how students collaborate in a group is successful. On the other hand, Nihalani also says when a group performance reflects the groups' member level instead of the whole group together. In summary, Badache (2011) explained group work is an instruction method where students of different levels work together for a specific objective. The essence of this method is to work together in a group with different members' levels to discuss a specific objective.

\section{Cooperative Project Tasks}

The third task is a cooperative project. It is discovery learning where a topic will be chosen by students. Students will be divided into several groups or 
pairs. They may have a different topic to discuss. They can research it on the Internet, interviews, libraries, and so on. In the end, they must present in front of the classroom. In the cooperative project, it has several more activities.

According to Olsen and Kagan (1992), CLL has three activities, the first of which is the three-step Interview. In this activity, students will work in pair. The role involves one of the members acting as the interviewer and the other, the interviewee. They will learn based on their sharing by doing the interview. Next, a roundtable activity called Round Robin. Students will work in a group. Each group will be given one pen and a piece of paper. One member of a group will make a contribution and then pass it to the other member. Each member contributes orally in turn. The third activity is solve-pair-share: the teacher will tell students about a problem, to which each student needs to find a solution individually. They explain their strategy to solve the problem by doing the interview or Round Robin structures.

\section{Think-Pair-Share}

After that, Think-Pair-Share (TPS) is one of the CLL activities. It is a problem-solving task. Kusrini (2012) mentioned that the Think-Pair-Share method gives students more opportunities to be active in sharing, thinking, and pairing with others. Furthermore, TPS strategy has a positive impact on students' learning interest in the teaching process, according to Kaniyem (2010). This activity can help students to solve a problem easily. Moreover, Lyman in Astiyandha (2013) suggested that there are seven advantages of Think-Pair-Share methods. It is quick and time saving. A discussion is more productive and gives students more time to think before students share it. Students have a chance to study higher-level thinking skills from their peers and increase their self-trust when they present for the whole class. The 'pair' step ensures that no student is out of a discussion and each student will have their time to speak. Students and the teacher gain a chance to think and argue in group discussion. This technique can be used for all grade levels and class sizes.

This technique seems to have both advantages and weaknesses. Diyah et al (2013) mentioned two weaknesses of TPS. First, not all students will pay attention to the topic given because they can discuss it together with their pair. 
Second, a student with a low understanding about the topic will do a conversation with others about a different topic. As a result, students sometimes underestimate a topic given by the teacher. What is more important is that Think-Pair-Share helps students to learn how to create a democratic moment when they are free to argue and suggest a topic (Kusrini (2012). This method is not just for helping students to solve a problem but also to train their critical thinking skills to come to solutions. The last activity is numbered heads, which is done in a traditional classroom. Each student will call a number. They will be divided into a team. The teacher will ask a question to each group, which will in turn head together and discuss about the question and make sure each member can explain the answer. The teacher will call a student's number to explain the result.

\section{Previous Studies on CLL Implementation}

Some previous studies have been done on cooperative learning in English language classrooms to enhance Yemeni students' speaking skills and attitudes (Attamimi, 2014). To collect the data, the researcher used a quasi-experimental method. The participants were sixty undergraduates at Hadhramout Unversity in Yemen. The results showed substantial learner speaking abilities and attitudes after using cooperative learning methods.

Another study was done by Christie and Listyani (2018) aimed at finding teachers' strategies to improve students' self confidence in speaking at SMK 1 and SMK 2 in Tamiang Layang. The participants were four teachers from different schools: SMK1 and SMK 2 in Central Borneo, Indonesia. These teachers used four strategies such as role-play, storytelling, small group discussion, and songs. The results of the research showed that the strategies were very useful to support students' self-confidence in speaking because every strategy gives students more opportunity to practice their speaking. Another study done by Dahler (2020) on 48 students from class VII of SMP Bina Mitra Wahana Pekanbaru also found that Community Language Learning (CLL) method effective for teaching speaking skill. Dahler's (2020) study was also supported by Ilyas (2017), whose study concluded that CLL gave good influence on students' speaking skill. It was found that CLL helped students to 
express ideas systematically; the ideas were well-organized, understandable, and standardized. Moreover, CLL improved the result of students' score in speaking skill. The mean score increased from 54.74 in pre-test to 72.86 . In summary, these studies showed that CLL could give more chances to students in learning the English language because it has several activities and tasks that give students more opportunity.

\section{RESEARCH METHOD}

This research was conducted at an elementary school in Taiwan between from October to November 2019. The school was chosen because the English teacher there implemented CLL in the English classroom. One of us was doing her teaching practicum in the school. She thus had a double role, as a researcher and a student-teacher. The student-teacher taught from third-fifth grades in elementary school.

\section{Research Participants}

The participants of this study were one English teacher and 64 Taiwanese elementary school students. They were fourth and fifth-graders selected for their relatively high English ability level. Each grade consisted of 32 students. The Taiwanese English teacher there was the only one, among eight English teachers altogether, who was willing to be interviewed and give more information about implemented CLL in teaching the English language. Busy activities and schedule clashes had been the biggest problems for us for not being able to interview the other teachers.

\section{Research Design}

This study used qualitative methods to get the results. According to Flick (2014), qualitative research was interested in analyzing issues, practices, social production by gathering non-standardized data, texts and images rather than numbers and statistics. The point was not just analyzing numbers but the progress of learning in each participant like what they felt about the method that the English teachers used to encourage them to speak the English language. The purpose of using this method was that the student-teacher can analyze each students' progress in learning the English language. 


\section{Data Collection Instruments}

The research instruments were semi-structured interviews and reflective journals. The first method was a semi-structured interview. This was conducted with one of the English teachers because she taught every grade of Elementary School. This method would help to answer the first research question of this study about how the teacher used CLL in speaking activity at a Taiwanese Elementary School. The second method was reflective journals, which was done for the fourth and fifth-grade elementary school students. This method would show what the students' responses were in speaking activities with the use of CLL. The participants were given reflective questions after the English lesson for speaking using CLL.

\section{Data Analysis Procedures}

After completing the data collection policies from the semi-structured interview and reflective journals, the results were analyzed. The result of the semi-structured interview showed the ways the teacher implemented CLL in speaking activities at the elementary school. The reflective journals exposed students' responses in speaking activities with the use of CLL. After all the data were gathered, the interviews were transcribed and reflective journals were identified based on the participants' responses. From all the data collected, themes were drawn.

\section{FINDINGS AND DISCUSSION}

This part explained the semi-structured interview and reflective journals by the English teacher and the fourth until the fifth-grade students at a Taiwanese elementary school. The findings were about how the English teacher implemented CLL in speaking activities and what the students' responses were during the speaking activities using CLL at the elementary school.

\section{How CLL was Applied in Speaking Activities}

The semi-structured interviews were recorded by the studentteacher-one of the researchers. The English teacher used CLL activities to help students in the learning of the English language. The interviewee was Teacher A. She had had an experience of about ten years in teaching 
English. At school, students usually still spoke in Taiwanese language during the English lesson. Teacher A mentioned in the interview that the students liked to speak Taiwanese most of the time. Therefore, the teachers could not force students too much to speak in English because foreign languages were rarely spoken outside of the classroom. The English teachers had their own methods to handle it. Teacher A mentioned in the interview that she applied CLL as stated in the excerpt below.

Excerpt 1:

"The way students practice speaking, we use a board game. Students need to practice board game in English because there are so many sentence patterns. Teachers use Cooperative learning strategies such as think-pairshare and group discussion (these are explained in the later section). In wrap-up activity, students write and speak the English language in a group." (The interview with the English teacher, Oct 14, 2019)

The teacher gave students motivation during learning English language. Teacher A said

\section{Excerpt 2:}

"On the whiteboard, I make a column with five layers. Each layer equals one point. If a student speaks in English correctly, the students' name will cling to a column. The highest score will get a reward" (The interview with the English teacher, Oct 14, 2019)

Based on the interview results, the English teacher used some CLL activities - pair group practice and group discussion. During the lesson, the teacher encouraged students by giving a reward for students who speak English properly. As a result, many students were encouraged to speak in English.

\section{Students' Responses in Speaking Activities Using CLL}

This part discussed the results from the reflective journals. The reflective questions were based on group discussions and Think-Pair-Share activities. These journals were given to the students after they got the activities, which were based on CLL.

\section{Group Discussion}

In the first cooperative activity, the student-teacher taught the fifth-grade students a lesson on animals. In the activity session, the student-teacher gave 
the guessing game. Students were given some descriptions of one animal. For example, lives under the sea and has eight tentacles. Students had to guess the name of that animal. Students were divided into several groups consisting of three or four people. Each group had one green board to write the answer. This game had five rounds. The winning group would get a gift from the student-teacher. The game went well. At the end of the lesson, students were asked to answer three reflective questions. The results are explained in the graphic below. This is clarified in Figure 1.

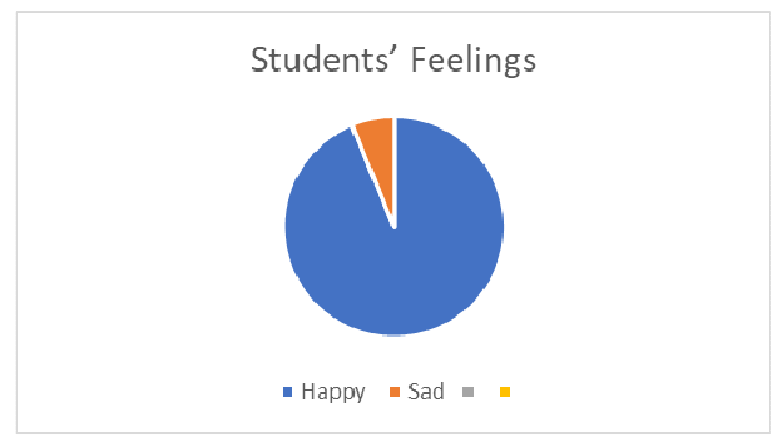

Figure 1. Grade V Students' Feelings

The result of the data from the reflective journal is as follows. Based on a group discussion related to the first reflective question, 30 out of 32 students $(93.75 \%)$ in the fifth grade replied, "I feel very happy because the game is fun." The other two out of 32 students (6.25\%) did not reply.

The second reflective question was about the problems of speaking English that the students faced. The result is demonstrated in Figure 2.

It was shown that 22 out of 32 students $(68.75 \%)$ in the fifth grade answered that they did not have a problem by replying " No, I don't " and 10 out of 32 students (31.25\%) faced a problem by answering "Yes because I don't know how to speak English." It means that the problem was represented by their lack of knowledge about how to speak in English.

The third reflective question was about the students' self-confidence in speaking. This result is clarified in Figure 3. 


\section{Problem in speaking}

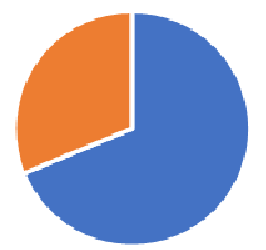

- No problem | Problem -

Figure 2. Problems Faced by Students in Speaking English

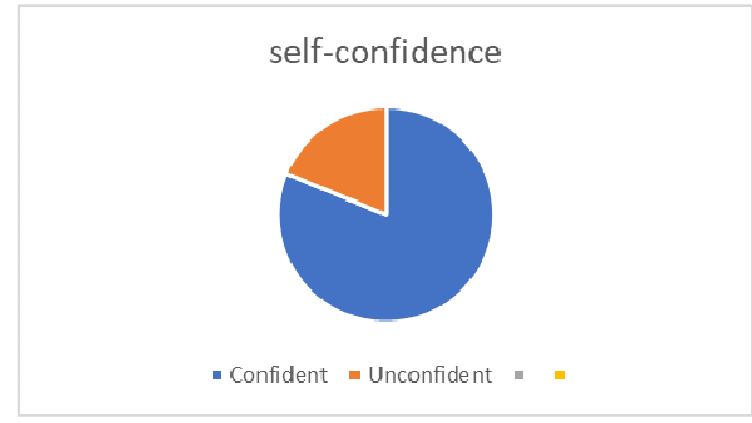

Figure 3. Students' Self-Confidence

Twenty-six out of 32 students (81.25\%) felt satisfied " Yes, because I learn so much English". Six out of 32 students (19.75\%) answered: "No because the words are hard."

In short, most of the students wrote that they enjoyed the activity when they learned in a group even though some students spoke their mother tongue several times.

\section{Think-Pair-Share / Pair Group Practice}

In the second cooperative activity, Think-Pair-Share, the student-teacher taught the fourth-grade students about Can you swim? In this activity, the student-teacher played the song called "What can you do?" The students and student-teacher danced and sang together. In the whilst teaching, students were taught about the sentence patterns and vocabulary inside the student 
book. This is clarified in Figure 4. The result is then elaborated in Figure 5. In the student book, it had a game called snake and ladders. Students were divided into pairs or a group of two. In that game, students played it by asking and answering based on the dialogue.

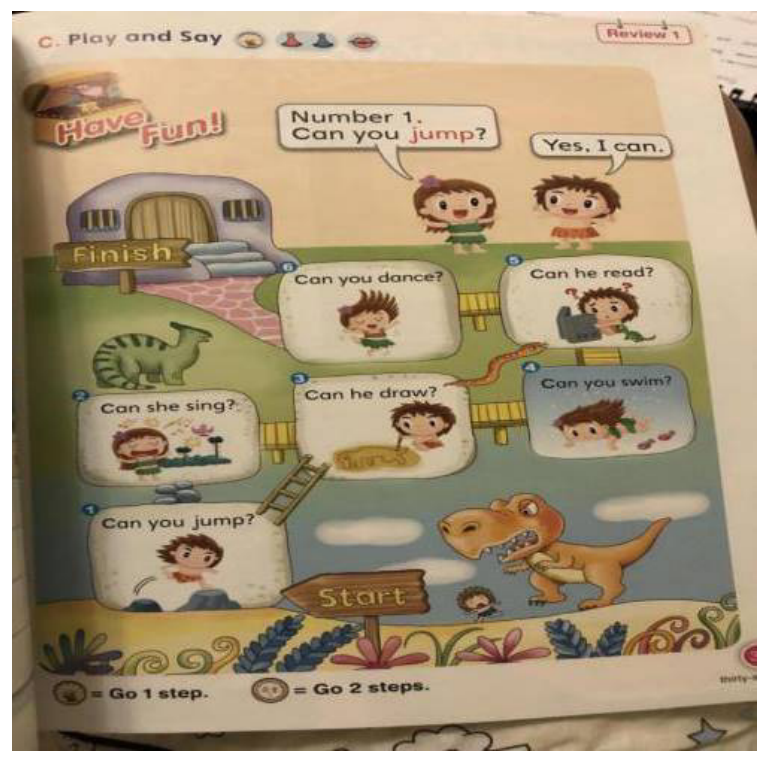

Figure 4: Snake and Ladders Game for Grade IV

The data from the reflective journals dealing with speaking activities were shown in in Figure 5.

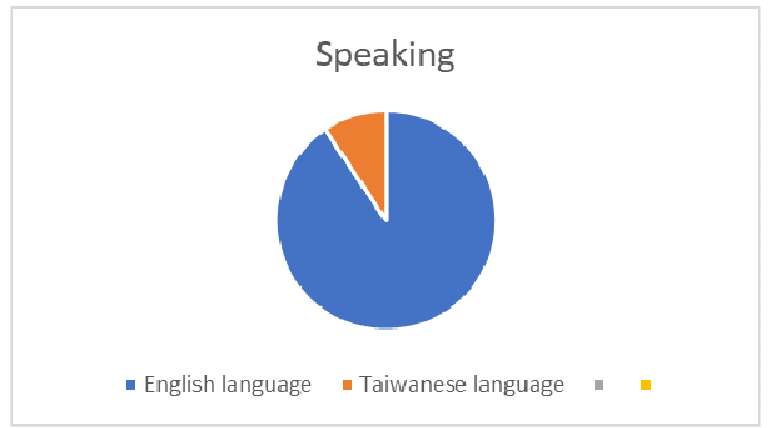

Figure 5. Think-Pair-Share 
Based on Think-Pair-Share activity, 29 out of 32 students in the fourth grade $(90.62 \%)$ thought that the game was fun and the sentences were quite easy by saying "It's fun and the words are easy". However, while playing the game, three out of 32 students (9.48\%) still preferred speaking in their mother tongue, Taiwanese, because in the students' opinion, they felt more confident in speaking their first language.

In short, in the first CLL activity, many students were able to speak and did not have a problem with speaking the English language. Overall, when the student-teacher did the oral practice with GIF pictures, students were excited to answer the student-teacher's questions. In addition, when they discussed in a group, most of them spoke in the English language. This is in line with Hamzah and Ting's (2010) theory stating that the students' responses about the group work activities of CLL showed positive feedback.

In the second CLL activity, 29 students thought the sentence patterns were easy. The student-teacher used snake and ladder games with a dialogue. Students could practice in pair. This intersects with (2012)Kusrini's theory that the Think-Pair-Share strategy gives students more chances to be active in sharing, thinking, and pairing each other. They could speak in English pretty loud and clear. Even though, fewer students preferred to speak the first language by translating the dialogues into the Taiwanese language. Overall, Bourner (2003) and McGuiness \& Brien (2007) mentioned that one of the judgment instruments for a teachers is reflection. The students' reflections could show their real feelings and effects on the CLL strategy that the teacher used.

\section{CONCLUSION}

From this study, it was found that the Taiwanese English teacher used CLL activities such as think-pair-share and group discussion. These activities could help students study the English language. The reason behind the teacher's use of CLL was because it has many activities that allow students more time to speak. Moreover, the teacher also gave students an element of surprise to reduce the students' use of mother tongue. 
Besides, the students' responses to CLL activities showed positive replied. First, from the group discussion, the student-teacher used a guessing game inside the classroom. More than half of the students enjoyed the class during CLL activities because they did not have a problem with speaking, even though some students still spoke in their mother tongue language. Second, from ThinkPair-Share, the student-teacher used the snake-and-ladder game with dialogues. 91 percent of the students stated that the sentences from dialogues were easy. The other nine percent of the students preferred to translate the sentences into their first language. Overall, many students were capable of speaking English properly because CLL activities were fun.

Unfortunately, there was a limitation during collecting data which became the major weakness of this study. Eight English teachers taught Elementary School students. The plan was to interview at least two of them but it could only be done with one English teacher, and it was only once. This happened because their schedules were busy. At least, the researcher was able to interview the English teacher who taught all grades of the elementary school. Other than that, the reflective journals were initially planned to be done three times, but it was done only once during a group discussion activity.

Seen from the students' abilities, it can be concluded overall that the students still lacked vocabulary for showing what they felt. This pushed the researcher to do the reflective journal for Think-Pair-Share activity orally.

There are some suggestions for future researchers, such as conducting more interviews with more respondents and writing a reflective journal protocol with their first language. This kind of research may have a good impact on helping students' with their speaking and giving suggestions for English teachers in choosing a strategy.[rgt]

\section{REFERENCES}

Abdulah, A. (2016). Group works activities for improving speaking skills. English Education Journal, 7(3), 389-401. Retrieved from http://www.jurnal.unsyiah.ac.id/EEJ/article/view/4591 
Alamri, H. R. H. (2018). The effect of using the Jigsaw cooperative learning technique on Saudi EFL students' speaking skills. Journal of Education and Practice, 9(6), 65-77. Retrieved from https://pdfs.semanticscholar.org/e5d8/ 34eab5855ac3c980a7c918d96e7e2ee0ee43.pdf

Astiyandha, T. (2013). The effectiveness of Think-Pair-Share Method to teach reading comprehension viewed from students' motivation. A Thesis. UNS.

Attamimi, R. A. (2014). Effectiveness of Cooperative learning in enhancing speaking skills and attitudes towards learning English. International Journal of Linguistics, 6(4), 27-45. Retrieved from https://pdfs.semanticscholar.org/ daf0/8049c122e864108f202a2581c2f03b7ba281.pdf

Bahsan, B \& Holsblat, R.(2017). Reflective journals as a research tool: The case of student teachers' development of teamwork. Teacher Education and Development, 1-15. Retrieved from https://www.tandfonline.com/ doi/pdf/10.1080/2331186X.2017.1374234

Cahyani, F. (2018). The use of think pair share technique to improve students' speaking performance. Research in English and Education, 3(1), 76-90. retrieved from http://www.jim.unsyiah.ac.id/READ/article/view/9237/ 3876

Christie, L. S. \& Listyani, L. (2018). Teachers' strategies to improve students' selfconfidence in speaking. Register Journal, 11(2), 121-138. Retrieved from https://www.researchgate.net/publication/329294842_Teachers'_Strategi es_to_Im prove_Students'_Self-

Confidence_in_Speaking_A_Study_at_Two_Vocational_S chools_in_Central_Borneo

Desta, R.A. (2017). Think pair share technique in teaching speaking skill. Research in English and Education, 2(1), 37-46. Retrieved from http://jim.unsyiah. ac.id/READ/article/view/2597/1432

Duxbury, J. G. \& Tsai, L. (2010), The effects of Cooperative learning on foreign language anxiety: a comparative study of Taiwanese and American universities. International Journal of Instruction, 3(1), 2-18. Retrieved from http://www.eiji.net/dosyalar/iji_2010_1_1.pdf

Dahler, D. (2020). Community language learning (CLL): Empowering speaking skill at SMP Bina Mitra Wahana Pekanbaru. El-Lectura Journal, 2(1). Retrieved from https://journal.unilak.ac.id/index.php/ELT-Lectura/article/view/460 
Esiri, J.M., Ajasa, A.O., \& Edomi, E. (2017). Observation research: A methodological discourse in communication research. Research on Humanities and Social Sciences, 7(20), 84-89. Retrieved from https://pdfs.semanticscholar.org/ aeb1/df2a97969617f6ca984edbf4c75e38b2caecpdf

Fung, Y. M., \& Hoon, T. B. (2013). The use of reflective journal in a postgraduate research methodology course: student experience. Pertanika Journal, 21, 4156. Retireved from https://www.researchgatenet/publication/ 290655996_The_use_of_reflective_journal_in_a_postgraduate_research_meth odology_course_Student_experiences

Gordon, T. (2007). Teaching young children a second language. London: Westport.

Hanan A. T. \& Nowreyah A. Al-Nouh. (2014). Effect of group work on EFL students' attitudes and learning in higher education. Journal of Education and Learning, 3(2), 52-65. Retrieved from https://files.eric.ed.gov/fulltext/EJ1076424.pdf

Hengki, H., Jabu, B., \& Salja, K. (2017). The effectiveness of cooperative learning strategy through English village for teaching speaking skill. Journal of Language Teaching and Research, 8(2), 306-312. Retrieved from http://www.academypublication.com/ojs/index.php/jltr/article/view /jltr0802306312/1058

Hosni, S. A. (2014). Speaking difficulties encountered by young EFL learners. International Journal on Studies in English Language and Literature, 2(6), 2230. retrieved from https://www.researchgate.net/publication/ 270340628_Speaking_Difficulties_Enc ountered_by_Young_EFL_Learners

Hussain, S. (2017). Teaching speaking skills in communication classroom. International Journal of Media, Journalism and Mass Communications, 3(3), 14-21. Retrieved from https://www.researchgate.net/publication/ 325650985_Teaching_Speaking_Skills in_Communication_Classroom

Ilyas, M. (2017). The Influence of CLL on EFL Learners' Speaking Skill. J-SHMIC: Journal of English for Academic Articles. Retrieved from https://journal.uir.ac.id/ index.php/jshmic/article/view/1987

O’Keeffe, J., Buytaert, W., Mijic, A., Brozović,N., \& Sinha, R. (2016). The use of semistructure interviews for the characterization of farmer irrigation practices. Hydrology and Earth System Science, 20, 1911-1924. Retrieved from https://www.hydrol-earth-syst-sci.net/20/1911/2016/hess-20-19112016.pdf 
Kessler,C. (1992). Cooperative language learning. New Jersey: Englewood Cliffs.

Maulani etal. (2019).Teaching speaking by using think-pair-share teaching strategy. The Journal of English Literacy Education, 6(2), 102-106. Retrieved from https://ejournal.unsri.ac.id/index.php/jenglish/article/download/9951/52 04

Munawar, M. (2015). Improving speaking skills through the learning community technique. English Education Journal, 6(4), 484-496. Retrieved from http://www.jurnal.unsyiah.ac.id/EEJ/article/download/2857/2719

Kinahan, M. P. 2017. Teacher and seating arrangements and assignments: a qualitative study (thesis). Boston: Northeastern University. Retrieved from https://repository.library.northeastern.edu/files/neu:cj82q019x/fulltext.pd $\mathrm{f}$

Partiwi, A. N. 2014. Improving speaking skills through cooperative language leaning for seventh grade of SMPN 4 Yogyakarta in the academic year of 2013/2014. A Thesis. Universitas Negeri Yogyakarta.

Prayoga, F. (2018). The impact of topic based group discussion pf EFL learners' speaking performance. Journal of Research and Method in Education, 8(2), 4045. Retrieved from http://www.iosrjournals.org/iosr-jrme/papers/Vol8\%20Issue-2/Version-6/H0802064045.pdf

Rahman, M. S. (2017). The advantageous and disadvantageous of using Qualitative and Qualitative approached and methods in language "Testing and Assessment" research: a literature review. Journal of Education and learning, 6(1), 102-112. Retrieved from http://www.ccsenet.org/journal/ index.php/jel/article/download/64330/34611

Rahmawati, R. (2017). Improving English speaking ability using the teamgames-tournament technique. English Education Journal, 8(1),1-13. retrieved from http://www.jurnal.unsyiah.ac.id/EEJ/article/view/6124

Roswati, M. \& Zaim, D. R. (2014). Improving students' speaking skill by using ThinkPair-Share strategy at the second emester of Syariah class A at language center of UIN Suka Riau. Journal English Language Teaching, 2(1),1-12. retrieved from http://ejournal.unp.ac.id/index.php/elt/article/download/ $4602 / 3642$ 
Laura Yosephine Tan, Listyani Listyani

Hermiati. (2017). The effectiveness of think pair square strategy in teaching students' listening comprehension at the second grade in SMA Negri 3 Sidap. A thesis. Universitas Islam Negeri Alauddin Makassar.

Wang, W. 2017. Improving students' oral skills through a cooperative learning approach to teaching Chinese college English. A thesis. University of Victoria.

Yulianingsih, L. (2014). The use of think pair and share technique in teaching reading to the seventh grade of senior high school. Language, Education and Literature, 5(2), 99-108. Retrieved from https://pdfs.semanticscholar.org/9bf4/527ade86afe003808d0d87fb8059 092b22fe.pdf 